\title{
(1234) Proposal to conserve the name Acanthoceras Honigm. (Bacillariophyceae) against Acanthoceras Kütz. (Rhodophyceae)
}

Mark B. Edlund ${ }^{1} \&$ Michael J. Wynne ${ }^{2}$

(1234) Acanthoceras Honigm. in Arch. Hydrobiol. Planktonk. 5: 76. 16 Oct 1909 [Bacillarioph.: Acanthocerat.], nom. cons. prop.

Type: A. magdeburgense Honigm.

(H) Acanthoceras Kütz. in Linnaea 15: 731. Feb-Mar 1842 [Rhodoph.: Ceram.], nom. rej. prop.

Type: A. shuttleworthianum Kütz.

A recent paper (Edlund \& Stoermer in J. Paleolimnol. 9: 55. 1993) noted the illegitimate status of the diatom Acanthoceras Honigm. as a later homonym of the red alga Acanthoceras Kütz. Kützing (in Linnaea 15: 731, 739. 1842) established Acanthoceras with the sole species $A$. shuttleworthianum Kütz., and later (Sp. Alg.: 684. 1849) added A. echionotum (J. Agardh) Kütz., A. transcurrens Kütz., and $A$. oxyacanthum Kütz. A. shuttleworthianum has long been treated as belonging to Ceramium Roth 1797, nom. cons. (J. Agardh, Spec. Gen. Ord. Alg. 2: 132. 1851; Silva in Taxon 8: 64. 1959; Dixon in J. Mar. Biol. Assoc. U. K. 39: 331, 375. 1960; Maggs \& Hommersand, Seaweeds Brit. Isles 1(3A): 72. 1993). The other three species once assigned to Acanthoceras have been placed within the taxonomic synonymy of C. echionotum J. Agardh (DeToni, Syll. Alg. 4(3): 775. 1903). With the exception of Centroceras Kütz., the eight or so genera segregated from Ceramium by Kützing (in Linnaea 15: 727. 1842; Phycol. General.: 381. 1843; Sp. Alg.: 684. 1849) have never gained acceptance. When Norris (in Bot. Mar. 36: 389. 1993) recently proposed to narrow the generic limits of Ceramium, he made no attempt to resurrect Acanthoceras Kütz.

Honigmann (in Arch. Hydrobiol. Planktonk. 5: 71. 1909) described the unispecific freshwater diatom genus Acanthoceras based on A. magdeburgense Honigm. (including var. latum Honigm.). Honigmann's Acanthoceras was not immediately accepted by the scientific community; e.g., Schulz (in Bot. Arch. 24: 505. 1929), Hustedt (in Rabenh. Krypt.-Fl., ed. 2, 7(1): 367. 1930) and Huber-Pestalozzi (in Binnengewässer 16(2): 424. 1942) treated A. magdeburgense as a taxonomic synonym of Attheya zachariasii Brun.

West (in Trans. Roy. Microscop. Soc. London, ser. 2, 8: 147. 1860) erected Attheya based on the marine species $A$. decora T. West. Later, Brun (in Forschungsber. Biol. Stat. Plön 2: 53. 1894) described the freshwater taxon A. zachariasii. The only other freshwater taxa ever assigned to Attheya $\mathrm{T}$. West were $A$. lata Wolosz. (in Kosmos (Lvov) 37: 134. 1912), nomenclaturally independent of Acanthoceras magdeburgense var. latum Honigm., and Attheya zachariasii var. curvata P. Rivera (in Bol. Soc. Biol. Concepción 47: 89. 1974).

\footnotetext{
${ }^{1}$ Center for Great Lakes and Aquatic Sciences, University of Michigan, Ann Arbor, MI 48109-2099, U.S.A.

${ }^{2}$ Herbarium and Department of Biology, University of Michigan, Ann Arbor, MI 48109-1048, U.S.A.
} 
Simonsen (in Bacillaria 2: 55. 1979) recognized differences between Attheya decora and $A$. zachariasii and proposed reinstating Acanthoceras Honigm. as a unispecific freshwater genus, making the combination Acanthoceras zachariasii (Brun) Simonsen, and placing Honigmann's $A$. magdeburgense and var. latum in synonymy. Separation of Acanthoceras from Attheya is clearly supported by ecological and ultrastructural differences (Round \& al., Diatoms: 338, 340. 1990; Crawford \& al. in Diatom Res. 9: 27. 1994). Acanthoceras is currently held to be a cosmopolitan unispecific genus inhabiting eutrophic freshwater rivers, lakes and ponds (Krammer \& Lange-Bertalot in Ettl \& al., Süsswasserfl. Mitteleur. 2(3): 83. 1991). The freshwater habit and published descriptions of Attheya lata and A. zachariasii var. curvata suggest that they too belong within the circumscription of Acanthoceras. Acanthoceras Honigm. has gained general acceptance in spite of its iilegitimate status (Round \& al., Diatoms: 338 1990; Krammer \& Lange-Bertalot in Ettl \& al., Süsswasserfl. Mitteleur. 2(3): 83. 1991; Edlund \& Stoermer in J. Paleolimnol. 9: 55. 1993; Greuter \& al. in Regnum Veg. 129: 3. 1993) and provides the basis for the recently proposed, equally illegitimate family name Acanthocerataceae R. M. Crawford \& Round (in Round \& al., Diatoms: 657. 1990). Its status as a later homonym of Acanthoceras Kütz. has been recognized for some time (Farr \& al. in Regnum Veg. 100: 5. 1979). We now propose that it be conserved. Recent discussions among diatomologists (Compère in Hydrobiologia 269-270: 515. 1993) support this proposal which, if accepted, will also legitimize the family name Acanthocerataceae.

The other option available to correct this situation is to publish a new genus and family name for this small diatom group. These transfers could be easily made as Acanthoceras Honigm. is considered unispecific by most. However, erecting a new genus and family would be in disagreement with the resolutions quoted in the Preface of the Tokyo Code, that displacing well established names for strictly nomenclatural reasons should be avoided.

\section{Acknowledgements}

We thank Dr E. F. Stoermer for support, and Dr Jadwiga Sieminska and Dr C. W. Reimer for providing literature. This paper represents publication 579 from the Center for Great Lakes and Aquatic Sciences and was funded through NSF grant DEB9521882 to Dr Stoermer. 